\title{
SIGNIFIKANSI PERUBAHAN SIKAP PERILAKU (BEHAVIOR) DALAM PROSES KEDIKLATAN
}

\author{
Ahmad Fauzi \\ Badan Pengembangan Sumber Daya Manusia Provinsi Riau
}

\begin{abstract}
There have been a lot of funds spent by the government for a number of disciplinary processes, but the resulting outcomes have not been able to answer changes in the behavior of the apparatus for the better. This paper highlights the behavior of the apparatus after following the training, not yet completely changing the essential attitude such as increasing the value of honesty, commitment, and ethics. The results of the study show that in order to conduct apparatus education and training it can give a better and more effective meaning as a result of learning, it is necessary (1) leadership commitment to obey the principles in organizing education and training, (2) the curriculum that is designed must be the needs of the participants and the weight of behavior change is more directed towards the affective domain, and 3) gives reward and punishment to the apparatus in accordance with their behavior.
\end{abstract}

\begin{abstract}
Abstrak: Telah banyak dana yang dikeluarkan pemerintah untuk sejumlah proses kediklatan, namun outcomes yang dihasilkan belum mampu menjawab perubahan perilaku aparatur ke arah yang lebih baik. Tulisan ini menyorot perilaku aparatur setelah mengikuti diklat, belum sepenuhnya terjadi perubahan sikap yang esensial seperti peningkatan nilai kejujuran, komitmen, dan etika. Hasil kajian menunjukkan bahwa agar penyelenggaraan diklat aparatur dapat memberi makna yang lebih baik dan efektif sebagai hasil pembelajaran, maka diperlukan (1) komitmen pimpinan untuk taat azas dalam penyelenggaraan diklat, (2) kurikulum yang didesain harus merupakan kebutuhan (need) para peserta dan bobot perubahan perilaku lebih banyak diarahkan kepada ranah afektif, dan 3) berikan reward and punishment kepada aparatur sesuai dengan perilakunya.
\end{abstract}

Kata kunci: perilaku aparatur, DIklat, komitmen, reard and punishment

\section{PENDAHULUAN}

Pertanyaan paling mendasar terkait dengan masalah diklat aparatur di Indonesia adalah: Mengapa proses diklat yang dilakukan oleh lembaga diklat selama ini, belum sepenuhnya mampu merubah prilaku aparatur, terkait sikap prilaku (behavior/attitude)? Telah banyak dana yang dikeluarkan pemerintah untuk sejumlah proses kediklatan, namun outcomes yang dihasilkan belum mampu menjawab perubahan prilaku aparatur ke arah yang lebih baik. Apa dan dimana masalahnya?

Dalam kurikulum diklat pola baru yang diterbitkan olehLANRI yang memiliki sejumlah subject matter, dirasakan masih sebatas Knowledge and Skill $(K S)$. Namun bagaimana dengan perubahan terhadap sikap prilaku (attitude)? Mengapa setelah aparatur mengikuti diklat, belum sepenuhnya terjadi perubahan sikap yang esensial seperti peningkatan nilai kejujuran, komitmen, istiqomah, takut dosa dan etika, dan lain sebagainya. Mengapa aparatur masih terjerumus atau terperangkap dalam kasus tindak pindak korupsi dalam penyelenggaraan kepemerintahan? Padahal mereka telah berkali kali mengikuti pendidikan dan pelatihan, mulai dari diklat pra jabatan atau latsa, diklat kepemimpinan tingkat IV, diklat kepemimpinan tingkat III dan bahkan sampai dengan Lemhanas? Inilah yang menarik untuk dimunculkan dalam tulisan ini.

Diklat PNS memiliki kelemahan inheren dikarenakan paradigma belajar cognitivism yang melandasinya, mengkonseptualisasikan pengetahuan (knowledge) atau ranah cognitie dalam proses pembelajaran secara sempit. Akibatnya, Diklat PNS tidak akan pernah mampu memenuhi seluruh kebutuhan belajar aparatur pemerintah. Proses pembelajaran yang dilakukan terkesan untuk menghabiskan waktu dan terlihat sebatas peningkatan pengetahuan dan keterampilan saja. Apabila ditanya soal perubahan sikap prilaku (attitude) maka lembaga diklat belum mampu memberi jawaban secara fakta, karena belum dapat menunjukkan hasil kajian yang 
mendalam dan ilmiah.

Untuk mengatasi permasalahan ini, maka penulis mengusulkan constructivism sebagai paradigma alternative, dimana belajar dikonseptualisasikan sebagai proses individu dan sekaligus sosial kemasyarakatan. Dengan paradigma ini, pengembangan SDM tidak lagi dilihat sebagai kegiatan diklat semata, tetapi proses belajar yang bisa berlangsung baik dalam konteks diklat maupun dalam konteks pekerjaan dan lingkungan sosial yang lebih luas.

Dengan demikian, model Diklat nonklasikal yang belum terlaksana dalam sistem diklat Aparatur dapat diwujudkan secara nyata. Perubahan pesat dilingkungan eksternal dan internal organisasi pemerintah dewasa ini menimbulkan implikasi kebutuhan belajar yang besar bagi PNS. Secara eksternal, perubahan mindset komitmen Indonesia untuk ikut serta dalam berbagai perjanjian bilateral dan multilateral, baik pada lingkup regional maupun global merupakan tantangan berat yang menuntut aparatur pemerintah untuk bekerja lebih profesional agar mampu mendukung Indonesia untuk berada pada posisi kompetitif dalam pergaulan internasional.

Secara internal, sejak desentralisasi digulirkan, terjadi perubahan mendasar pada berbagai aspek penyelenggaraan administrasi negara baik di tingkat pusat maupun daerah. Hal ini menimbulkan implikasi perubahan belajar yang besar bagi aparatur pemerintah. Sejauh ini kebutuhan pengembangan kapasitas SDMAparatur kebanyakan dipenuhi melalui sistem Pendidikan dan Pelatihan Pegawai Negeri Sipil (diklat Aparatur), serta melalui pendidikan formal di Perguruan Tinggi (PT). Akan tetapi, sistem pengembangan SDM aparatur yang dititikberatkan pada Diklat formal seperti sekarang ini belum ada, dan bahkan tidak akan pernah mampu, membekali PNS dengan pengetahuan dan keterampilan yang diperlukan, untuk bisa melaksanakan tugas dan fungsi mereka secara efektif.

Hal demikian, bisa dilihat dari rendahnya mutu penyelenggaraan pelayanan publik yang tercermin dari banyaknya keluhan masyarakat yang disampaikan lewat media massa atau forum lainnya. Lantas bagaimana efektivitas Diklat PNS yang bertujuan untuk meningkatkan pengetahuan, keahlian, keterampilan, serta memantapkan sikap prilaku dan semangat pengabdian yang berorientasi pada pelayanan, pengayoman, dan pemberdayaan masyarakat yang disebutkan dalam Peraturan Pemerintah.

\section{METODE}

Mengapa Diklat PNS yang semakin gencar dilaksanakan selama ini, belum berhasil mengembangkan kapasitas aparatur pemerintah untuk bisa merubah sikap prilaku kearah yang lebih baik? Seperti memberi pelayanan publik yang berkualitas? Tidak semua Aparatur memahami tentang makna dari sebuah diklat? Tidak semua penyelenggara diklat memahami tentang Input, Proses, Output, Outcomes dari sebuah sistem diklat?

Untuk menjawab pertanyaan diatas,tidak cukup dengan hanya melihat Diklat PNS itu sendiri sebagai object atau pokok permasalahan. Akan tetapi perlu mencermati lebih jauh lagi tentang paradigma pengembangan SDM yang melatar belakangi diklat aparatur tersebut. Oleh karena itu, tulisan ini akan mengekplore paradigma cognitivism yang mendasari diklat aparatur (ASN) sehingga terbentuk pribadi yang amanah.

\section{HASII DAN PEMBAHASAN Paradigma Pembelajaran}

Bahwa sistem Diklat PNS di Indonesia masih memiliki kelemahan. Laporan Capacity Building Analysis oleh GTZ/USAID-CLEAN URBAN (2001) misalnya, mengindikasikan adanya ketidakpuasan akan sistem diklat struktural karena durasinya terlalu panjang, mahal, dan terlalu teoritis, serta tidak memadai untuk mengembangkan kemampuan dan keterampilan yang dibutuhkan oleh Pegawai.

Kelamahan yang paling mendasar adalah kenyataan bahwa Diklat formal hanya mampu mensuplai pengetahuan yang bersifat eksplisit, padahal pegawai justru memerlukan lebih banyak pengetahuan implisit untuk bisa melaksanakan tugas mereka secara efektif. Polanyi (1958, 1967), seorang ilmuan kimia yang beralih menjadi filosof, membagi pengetahuan kedalam dimensi eksplisit dan tacit. Menurutnya, pe- 
ngetahuan eksplisit mudah diungkapkan baik secara lisan maupun tulisan. Karena sudah terstruktur, pegawai dapat menemukannya dengan mudah dalam buku, manual, pedoman, laporan dan dokumen organisasi lainnya baik yang berbasis kertas maupun elektronik.

Akan tetapi, kelemahan pengembangan SDM aparatur terkait dengan faktor yang lebih mendasar lagi, yakni paradigma belajar yang dianut, yang kemudian melahirkan sistem Diklat PNS yang bersifat tradisional dan konvensional, yakni proses belajar berbasis ruang kelas dimana kurikulum, metode belajar, waktu, tempat dan aspek-aspek lainnya sudah diresepkan secara baku.

Pemahaman mengenai belajar telah didominasi oleh pandangan cognitivism yang disamping melihat proses belajar secara sempit, juga ditambah lagi oleh interpretasi dalam mengimplementasikan ke dalam desain instruksional pada Diklat PNS. Meskipun dalam Peraturan Pemerintah mengenal Diklat non-klasikal (nonkonvensional), tapi kenyataannya penyelenggaraan Diklat PNS masih dalam bentuk konvensional (klasikal). Kelemahan lain dari Diklat yang berbasis cognitivism adalah training transfer, yakni kesulitan mengaplikasikan apa yang telah dipelajari dikelas kedalam realitas pekerjaan sehari-hari.

Paradigma cognitivism lahir sekitar dekade 60-an sebagai upaya koreksi terhadap pandangan sempit aliran behaviourism (Skinner 1954, 1957; Watson, 1970) yang melihat proses belajar sebagai perubahan perilaku yang nampak dari luar. Bagi kalangan behaviourist, otak manusia merupakan kotak hitam yang tidak bisa diamati secara objektif sehingga tidak cocok dijadikan objek penelitian. Akan tetapi, cognitivist mengklaim bahwa otak manusia bukan kotak hitam yang misterius, dan bahwa proses mental di dalamnya bisa dan bahkan perlu dijadikan objek penelitian secara empiris (Mergel, 1998). Dengan demikian, bagi kaum cognitivist, belajar adalah kegiatan individu yang ditandai oleh perubahan dalam schema atau struktur pengetahuan dalam otak manusia. Alat ukurnya adalah daya ingat dan tingkat pemahaman.

Hal ini terjadi karena cognitivism me- misahkan antara belajar dan bekerja. Belajar dianggap sesuatu yang hanya bisa dilakukan pada waktu dan tempat tertentu yang terpisah dari waktu dan tempat dimana pegawai bekerja sehari-hari. Untuk mengembangkan kemampuan pegawai, mereka harus meninggalkan pekerjaan untuk secara khusus mengikuti proses pembelajaran di unit diklat.

Selama mengikuti diklat mereka terisolasi dari lingkungan otentik dimana hasil Diklat itu nantinya akan diaplikasikan. Isolasi seperti ini berlangsung cukup lama mengingat diklat PNS, terutama Diklat struktural, berlangsung dalam jangka waktu yang cukup lama pula, dan biasanya bersifat residensial, yaitu peserta Diklat menginap di asrama. Proses transfer pengetahuan pada saat belajar tersebut diassosiasikan dengan pemrosesan informasi pada computer yang meliputi rangkaian "input- proses-output" (IPO). Dalam hal ini, belajar merupakan proses pengkodean informasi yang diterima ke dalam memori (Input), lalu diassimilasikan kedalam struktur pengetahuan dalam otak atau schema (proses), dan selanjutnya disimpan untuk diakses jika sewaktu-waktu diperlukan (output).

Bagi penganut cognitivism pengetahuan sifatnya given, absolut, external reality yang terekam dalam benak individu. Jadi, otak manusia dilihat sebagai wadah yang diisi dengan pengetahuan yang sudah ada di luar sana melalui proses pembelajaran. Belajar bagi penganut cognitivism adalah proses transfer pengetahuan dari sumber yang kaya pengetahuan ke tujuan yang lebih miskin pengetahuan.

Sayangnya, sudut pandang cognitivism di atas merupakan penyederhanaan yang berlebihan dari proses belajar yang sesungguhnya merupakan fenomena yang amat kompleks. Kendati demikian, cognitivism tetap mendominasi pemahaman mengenai belajar, dan ini bisa dipahami mengingat kompatibilitasnya dengan hakekat legalitas formal birokrasi (efisien, terukur, predictable dan terkendali); suatu model organisasi yang dikemukakan oleh Max Weber, yang hingga kini masih dominan sebagai model organisasi pemerintah maupun swasta.

Krebs (1998), seorang konsultan mensejajarkan pengetahuan semacam ini dengan 
"data" yang mudah ditemukan dalam komputer dan tempat penyimpanan pengetahuan tradisional seperti filing cabinet. Jadi pengetahuan eksplisit bukanlah pengetahuan baru, tidak pula memiliki nilai competitif tinggi karena hanya merupakan pengetahuan dasar yang secara default perlu dimiliki oleh pegawai (know-what). Pengetahuan eksplisit inilah yang bisa dijadikan bahan atau materi dalam Diklat konvensional. Hal ini sesuai dengan pronsip Cognitivism yang memandang pengetahuan sebagai realitas eksternal dan otak manusia sebagai wadah pengetahuan, sehingga belajar direduksi menjadi proses tranfer pengetahuan eksplisit dari sumber yang banyak pengetahuan ke tujuan yang kurang pengetahuan.

Sejalan dengan itu, cognitivism menekankan pada proses belajar yang terukur, misalnya melalui penetapan tujuan belajar secara objektif, tegas, dan peserta dinilai dari kemampuan mereka mencapai tujuan belajar tersebut. Karena keterukurannya, peringkat peserta Diklat bisa ditentukan berdasarkan ukuran-ukuran baku, terutama dengan hasil ujian. Untuk menjamin objektivitas, kurikulum dan berbagai standar penyelenggaraan diterapkan secara seragam dan ini biasanya ditetapkan oleh satu institusi sentral. Lebih jauh lagi, kompetensi seorang pegawai sebagai output Diklat sering diukur menurut asas legalitas formal yang kaku seperti ijazah atau sertifikat apa yang dimilikinya, dan bukan pada apa yang mampu ia lakukan secara nyata. Dominasi pandangan cognitivism ini mempersempit kesempatan belajar bagi pegawai karena hanya belajar formal seperti Diklat konvensional dan pendidikan di universitas yang diangap sebagai arena pengembangan kapasitas.

\section{Keterbatasan Inheren dan Kendala Teknis Diklat Konvensional}

Diklat konvensional yang berlandaskan cognitivism seperti disebutkan di atas memiliki kelemahan inheren, sehingga meskipun diselenggarakan dengan sempurna, tetap tidak akan mampu mensuplai seluruh kebutuhan belajar yang diperlukan oleh pegawai. Hanya saja penyederhanaan diatas mengingkari dimensi lain dari pengetahuan yang justru lebih bermanfaat dalam mendukung pegawai dalam menyelesaikan pekerjaan.

Dimensi yang terabaikan ini diistilahkan oleh Polanyi sebagai pengetahuan tacit atau implisit. Pengetahuan semacam ini bersifat personal dalam arti ia melekat dan tersirat dalam praktek dan cara kerja pemiliknya sehingga susah untuk dikemukakan secara verbal atau tertulis. Pengetahuan tacit inilah yang biasa tercermin dalam sikap dan perilaku pegawai yang hingga kini belum dan tidak akan pernah bisa tersentuh dalam Diklat PNS selama masih diselenggarakan dalam bentuk konvensional.

Implikasinya adalah bahwa pengetahuan implisit ini susah untuk di transfer dari satu orang ke orang lain seperti yang terjadi dalam konteks Diklat formal. Krebs (1998) menganggap pengetahuan tacit sebagai "kecakapan" yang hanya bisa ditemukan dalam sistim biologis dan sistim sosial. Pemiliknya sering tidak menyadari bahwa ia memiliki pengetahuan semacam ini, dan jika dia meninggalkan organisasi maka pengetahuan tacit miliknya turut terbawa pergi (brain-drain). Kalaupun pegawai menyadari, pengetahuan tacit ini tidak akan mereka bagikan kepada orang lain secara sukarela karena ia memiliki nilai kompetitif yang tinggi.

Karakteristik lain dari pengetahuan tacit adalah sifatnya yang kontekstual, yakni terbangun di tempat kerja sehingga relevansinya dengan pekerjaan pegawai tidak diragukan. Yang lebih penting lagi adalah bahwa pengetahuan tacit sifatnya actionable dalam arti digunakan oleh pegawai untuk secara efektif menyelesaikan pekerjaannya (know-how). Pengetahuan tacit serupa dengan apa yang didapatkan melalui "double-loop learning" dalam teori Argyris dan Schon (1996), yakni belajar kearah perubahan nilai-nilai dan asumsi-asumsi dasar, dan bukannya mengenai apa yang terlihat di permukaan.

Beberapa ahli dan pemerhati masalah pembelajaran dalam organisasi mulai melirik dimensi pengetahuan yang tersembunyi ini. Pentingnya pengetahuan tacit terutama karena proporsinya yang jauh lebih banyak dibandingkan dengan pengetahuan eksplisit. Hal ini tercerin dalam pernyataan Polanyi (1967) bahwa "we can know more than we can tell" yang maksudnya 
pengetahuan kita jauh lebih banyak dari pada apa yang bisa kita ungkapkan secara verbal atau tertulis. Sebagian ahli yang berpendapat bahwa pengetahuan tacit lebih berharga ketimbang pengetahuan eksplisit.

Kepemilikan pengetahuan tacit inilah yang membedakan seorang maestro dari seorang novice (pemula). Nonaka dan Takeuchi (1995), dua orang peneliti pembelajaran dalam organisasi di Jepang, berpendapat bahwa keberhasilan perusahaan-perusahaan multinasional di Jepang lebih banyak ditentukan oleh kemampuan mereka mengembangkan kreativitas dengan mendorong pegawai untuk saling berbagi pengetahuan tacit. Kusterer (1978) menggunakan istilah "working knowledge" yang maksudnya sama dengan pengetahuan tacit, dan berpendapat bahwa pengetahuan semacam itu sangat bermanfaat dalam proses produksi atau pelayanan. Kendati peranannya penting, pengetahuan tacit yang tersembunyi ini tidak bisa dipelajari melalui Diklat formal mengingat karakteristiknya di atas.

Kelemahan lain dari Diklat tradisional yang berbasis Cognitivism adalah training transfer, yakni kesulitan mengaplikasikan apa yang telah dielajari dalam Diklat ke realitas pekerjaan sehari-hari. Hal ini terjadi karena Cognitivism memisahkan antara "belajar" dan "bekerja". Belajar dianggap sesuatu yang hanya bisa dilakukan pada waktu dan tempat tertentu yang terpisah dari waktu dan tempat dimana pegawai bekerja sehari-hari. Untuk mengembangkan kemampuan pegawai, mereka harus meninggalkan pekerjaan untuk secara khusus mengikuti proses pembelajaran di balai atau unit Diklat. Selama mengikuti Diklat mereka terisolasi dari lingkungan otentik dimana hasil Diklat itu nantinya akan diaplikasikan. Isolasi seperti ini berlangsung cukup lama mengingat Diklat PNS, terutama Diklat struktural, berlangsung dalam jangka waktu yang cukup lama pula, dan biasanya bersifat residensial, yaitu peserta Diklat menginap di asrama.

Permasalahan training transfer tersebut melahirkan anekdot "lain teori lain praktek", kendati sesungguhnyatidak demikian. Penerimaan anekdot di atas cenderung menjadikan Diklat sebagai formalitas dan bukan murni untuk tujuan pengembangan kapasitas, setidaknya dari sudut pandang peserta. Perlu dipahami bahwa belajar, terutama yang ditujukan untuk meningkatkan kapasitas dan kemampuan kerja, sifatnya kontekstual dan tidak bebas nilai. Sesuatu yang dianggap benar dan aplikatif di suatu tempat, sering tidak demikian halnya di tempat lain. Implikasinya adalah bahwa proses belajar yang paling ideal adalah yang terjadi di tempat kerja dimana pengetahuan yang didapat akan diaplikasikan. Dengan demikian substansi pengetahuan, keterampilan, beserta budaya organisasi yang membentuk sikap, perilaku bisa diinternalisasi secara simultan.

Kelemahan selanjutnya dari Diklat berbasis cognitivism adalah ketidakmampuannya sebagai arena pembelajaran untuk memenuhi kebutuhan belajar yang sifatnya konstan dan terus-menerus yang diakibatkan oleh perubahan lingkungan yang cepat dan peningkatan volume dan kompleksitas kerja. Hal ini disebabkan karena Diklat formal dibatasi oleh ruang dan waktu yang diakibatkan oleh pemisahan antara belajar dan bekerja dalam prinsip cognitivism sebagaimana dikemukakan di atas.

Kesesuaian antara materi Diklat dan kebutuhan belajar perserta yang memiliki tingkat pengetahuan, pengalaman, latar belakang dan lingkungan kerja yang beragam merupakan kelemahan lain dari Diklat konvensional. Hal ini terjadi karena hakekat belajar manusia, yang sesungguhnya kompleks, disejajarkan dengan proses IPO pada sistim komputer. Manifestasinya dalam Diklat PNS, misalnya, adalah bahwa selama penyelenggaraan Diklat peserta disuguhi dengan materi (Input) yang diharapkan bisa dicerna (Proses) sehingga bisa melahirkan pengetahuan, pemahaman dan keterampilan baru, beserta sikap dan perilaku yang lebih positif (Output) untuk kemudian dibawa pulang untuk diaplikasikan di tempat kerja mereka masingmasing. Akibatnya, Diklat PNS bersifat supplydriven dalam artian apa yang peserta pelajari tidak selalu berdasarkan kebutuhan real mereka, tetapi menurut apa yang dianggap oleh orang lain (seperti manajemen, perancang Diklat atau pembuat kurikulum) dibutuhkan mereka. Manivestasinya bisa dilihat dari kurikulum Diklat yang sarat dengan muatan materi yang belum 
tentu sesuai dengan kebutuhan peserta Diklat baik dari segi jenis maupun jumlahnya.

Dengan demikian, Diklat formal juga ingkar terhadap kebutuhan, gaya dan karakteristik belajar orang dewasa. Cross (1981) dalam penelitiannya menemukan bahwa karena sudah memiliki pengatahuan dan pengalaman yang luas, pelajar dewasa lebih suka mengendalikan keputusan mengenai apa yang mau dipelajari, bagaimana mempelajarinya, kapan dan dimana melakukan proses belajar tersebut. Tingkat pengetahuan, pengalaman, latar belakang dan lingkungan kerja yang beragam inilah yang menjadi penentu apa yang sebenarnya relevan untuk mereka pelajari. Ciri kemandirian dan fleksibilitas orang dewasa dalam belajar tersebut tidak bisa terakomodasi dalam Diklat konvensional yang kurikulum, metode belajar, waktu, tempat dan sebagainya sudah diresepkan secara baku.

Sinergi pengetahuan dan kemampuan yang merupakan karakteristik belajar orang dewasa yang sudah memiliki pengalaman terabaikan oleh prinsip individualist yang dipegang oleh Cognitivism. Dalam Diklat formal, keberhasilan peserta dinilai dari kemampuan individu menyerap pengetahuan yang disajikan, yang biasanya diukur melalui ujian formal (ada pengawas dan tidak boleh kerjasama) pada akhir proses pembelajaran. Bahkan ranking mereka biasanya ditentukan. Permasalahannya adalah bahwa kemampuan seseorang yang ditunjukkan oleh hasil ujian tidak mencerminkan secara akurat daya belajar, apalagi kemampuan orang tersebut dalam bekerja. Orang dewasa justru lebih banyak belajar melalui sintesis pengetahuan yang didapatkan melalui saling berbagi di tempat kerja maupun di tempat Diklat. Saling "menyontek" dalam konteks belajar orang dewasa justru menguntungkan dan perlu digalakkan, karena bisa mendukung proses sintesa pengetahuan yang akan melahirkan pengetahuan baru pada ordo yang lebih tinggi. Prinsip "keseluruhan lebih banyak dari jumlah bagian-bagiannya (The whole is more than the sum of its part)" kurang termanfaatkan dalam Diklat formal.

Disamping kelemahan inheren dari Diklat formal yang telah dikemukakan di atas, terdapat pula sejumlah kelemahan teknis pada Diklat formal bagi PNS.

Sebagaimana dikemukakan pada bagian awal tulisan ini, CBNA telah melaporkan kelemahan Diklat struktural yang durasinya terlalu panjang, mahal, dan isinya yang terlalu teoritis, serta tidak memadainya untuk mengembangkan kemampuan dan keterampilan yang dibutuhkan pegawai. Pada prinsipnya, kelemahan teknis itu bisa dilihat pada setiap kmponen dari siklus Diklat seperti analisa kebutuhan yang tidak diadakan atau tidak tepat, rancangan dan implementasi yang tidak sinkron, serta evaluasi yang tidak dilakukan secara benar dan hasilnya tidak digunakan secara serius untuk mengembangkan penyelenggaraan Diklat selanjutnya.

Ada sejumlah hal yang perlu dilakukan dalam rangka penyempurnaan sistem pengembangan SDM di sektor publik. Pertama, paradigma pengembangan SDM harus bergeser dari Cognitivism ke Constructivism. Paradigma Constructivism berasumsi bahwa pengetahuan tidak absolute, tetapi bersifat tentative dan tergantung bagaimana individu mengkonstruksi makna sembari berinteraksi dengan lingkungannya (Brunner, 1996; Murphy, 1997). Jadi Constructivism mengakui bahwa manusia adalah mahluk sosial dan belajar adalah proses dialektik yang tidak terjadi dalam social vacuum; dimama manusia mencoba mendekati kebenaran dengan mengkonstruksi dan merekonstruksi pemahaman mereka secara subjektif.

Hal ini akan menggeser fokus pengembangan SDM dari "Diklat" ke "belajar", dimana proses belajar tersebut tidak selalu harus berlangsung melalui Diklat tetapi bisa melalui cara informal. Dengan demikian proses belajar yang terjadi di luar konteks Diklat formal yang sesungguhnya banyak dan sangat bermanfaat dalam rangka pengembangan kapasitas pegawai bisa terapresiasi dan termanfaatkan.

Seiring dengan pergeseran ke paradigma Constructivism, Diklat PNS yang ada sekarang perlu pula direvitalisasi agar lebih mendewasakan orang dewasa. Secara kongkrit, Diklat perlu dirancang untuk memberikan lebih banyak keleluasaan kepada calon peserta untuk memilih apa sebenarnya kebutuhan belajar mereka dengan 
tidak menawarkan materi dalam bentuk paket.

Selainitu, penyelenggaraan Diklat sebaiknya dipecah kedalam beberapa segmen, dan setiap segment dilaksanakan dalam waktu yang berbeda. Solusi ini akan memberi kesempatan kepada peserta Diklat untuk kembali ke tempat kerja dan mencoba menerapkan apa yang telah mereka pelajari. Disamping itu, dengan teknik ini pegawai tidak perlu meninggalkan pekerjaan terlalu lama.Akhirnya, pandangan Constructivism akan dengan mudah mengakomodasi model pembelajaran melalui magang, mentoring, coaching, pelatihan di tepat kerja dan teknik pembelajaran non-konvensional semacamnya yang dalam Sistem Diklat PNS dikenal sebagai model Diklat non-klasikal, tetapi belum terlaksana.

Diklat PNS yang berbentuk konvensional tidak mampu membekali pegawai dengan pengetahuan yang diperlukan untuk bisa melaksanakan tugas secara efektif. Disamping karena kelemahan teknis dari model Diklat tersebut, terdapat pula sejumlah kelemahan inheren yang diakibatkan karena paradigma pengembangan SDM yang mendasarinya terlalu berorientasi cognitivist. Akibatnya, belajar terlalu disederhanakan menjadi proses tranfer pengetahuan dari sumber yang dianggap kaya pengetahuan (misalnya pelatih) ke orang yang lebih miskin pengetahuan (peserta Dilklat) sebagai upaya untuk mengisi otak manusia yang merupakan wadah pengetahuan.

Dalam berbagai penelitian (lihat misalnya Leslie et al., 1997; Day, 1998; Low et al., 2001; Nidumolu et al., 2001) disebutkan bahwa 70 hingga 90 persen dari pengetahuan orang dewasa didapatkan melalui proses belajar informal, yakni proses belajar yang tidak diatur, tetapi terjadi melalui interaksi antar pegawai di tempat kerja baik secara insidentil maupun disengaja. Karena sifatnya implisit dan pengetahuan yang terlibat juga implisit, Diklat formal tidak mampu menjangkau pengetahuan ini, dan karenanya pula sebagian besar pengetahuan yang peranannya sangat penting menjadi terabaikan.

Argumen di atas tidak menafikan peranan Diklat formal, akan tetapi mencoba menekankan bahwa Diklat formal tidak memadai karena hanya mampu mensuplai pengetahuan eksplisit (knowwhat), dan karenanya perlu ditunjang dengan proses belajar informal agar pegawai memiliki akses ke pengetahuan implisit (know-how) yang akan membantu mereka untuk melaksanakan tugas dan fungsi secara lebih berdaya guna. Dengan kata lain, hubungan antara Diklat formal dan belajar informal bersifat komplementer, bukan substitutive.

\section{SIMPULAN}

Berdasarkan uraian diatas, agar penyelenggaraan diklat Aparatur dapat memberi makna yang lebih baik dan efektif sebagai hasil pembelajaran, maka diperlukan (1) komitmen Pimpinan untuk taat azas dalam penyelenggaraan diklat (2) Kurikulum yang di desain harus merupakan kebutuhan (Need) para peserta dan bobot perubahan perilaku lebih banyak diarahkan kepada ranah Afektif (3) Berikan Reward and Punishment kepada aparatur pemerintah.

\section{DAFTAR RUJUKAN}

Argyris, C. \& Schon, D.A. 1996. Organizational Learning II: Theory, method and practice. Reading, Mass.: Addison-Wesley.

Cross, K. P. 1981. Adults as learners: Increasing participation and facilitating learning. California: Jossey-Bass.

Day, N. 1998. "Informal learning gets results." Workforce June: 31-36.

GTZ/USAID-CLEAN URBAN. 2001. Capacity building for local governance: A framework for government action and donor support (Final Report). Jakarta, GTZ, USAIDClean Urban: 1-64.

Krebs, V. 1998. Knowledge networks: Mapping and measuring knowledge creation and reuse [Online]. Available: http://www. orgnet.com/IHRIM.html [29 August 2001].

Kusterer, K. C. 1978. Know-How on the job: The important working knowledge of "unskilled" workers. Colorado: Westview Press.

Leslie, B., Aring, M. K. \& Brand, B. 1997. "Informal learning: The new frontier of employee and organizational development." Economic Development Review 15(4): 12-18. 
Low,A., Tjongarero,A., Low,A.\& Nambundunga, B. 2001. "Donor support to human resource capacity building in Namibia: Experience of resident technical assisnatce support for workplace learning and assessment of alternative options." Journal of International Development 13: 269285.

Mergel, B. 1998. Instructional Design \& Learning Theory [Online]. Available: http:/ /www.usask.ca/education/coursework/ 802papers/mergel/mergel.PDF [25 March 2003].

Nidumolu, S. R., Subramani, M. \& Aldrich, A.
2001. "Situated learning and the situated knowledge web: Exploring the ground beneath knowledge management." Journal of Management Information Systems 18(1): 115-150.

Nonaka, I. \& Takeuchi, H. 1995. The knowledgecreating company: How Japanese companies create the dynamics of innovation. New York: Oxford University Press.

Polanyi, M. 1958. Personal knowledge: Towards a post-critical philosophy. London, Routledge and Kegan Paul.

Polanyi, M. 1967. The tacit dimention. London: Routledge \& Kegan Paul. 